Travaux du Muséum National d'Histoire Naturelle

«Grigore Antipa»

Vol. LV (2) pp. 291-304

(C) 28 décembre

2012

DOI: $10.2478 / \mathrm{v} 10191-012-0019-5$

\title{
TERRESTRIAL SMALL MAMMAL COMMUNITIES FROM THE FĂGĂRAŞ PIEDMONT (ROMANIA)
}

\author{
ANAMARIA LAZĂR, CĂTĂLIN LAZĂR, \\ ANA MARIA BENEDEK, ANA MARIA ŞUVĂIALĂ
}

\begin{abstract}
So far 24 species of terrestrial small mammals are known from Făgăraş Piedmont, one of them (Chionomys nivalis) requiring further confirmation, as its presence at this elevation is put under question by the authors. In 2010 and 2011 three field campaigns were carried out in Făgăraş Piedmont, which targeted the abundance and structure of terrestrial small mammal communities in different habitats from three localities, using the capture-mark-release method. 61 transects of traps were installed in 9 types of habitats. 491 small mammals were captured belonging to 14 species, three shrews and 11 rodents. The highest densities were recorded in cultures and unused land, but specific diversity is not correlated with abundance.
\end{abstract}

Résumé. Jusqu'à présent 24 espèces de petits mammifères terrestres sont connues du Piémont Făgăraş, dont Chionomys nivalis nécessite une confirmation supplémentaire, car sa présence à cette altitude est discutable. En 2010 et 2011 trois campagnes de terrain ont eu lieu dans le Piémont Făgăraş. Ces campagnes ont visé la structure des communautés des petits mammifères dans les différents habitats étudiés en utilisant la méthode de capture-marquage-libération. 61 transects de pièges ont été installés dans 9 types d'habitats. 491 mammifères appartenant à 14 espèces, dont trois musaraignes et 11 rongeurs, ont été capturés. Les plus élevées densités ont été enregistrées dans les cultures et les terres en friche, mais la diversité spécifique n'est pas en corrélation avec l'abondance.

Key words: rodents, shrews, live trapping, community structure, habitat preferences, cluster analysis.

\section{INTRODUCTION}

The Făgăraş Piedmont represents the highest part of the depression with the same name, bordering the northern slope of Făgăraş Mountains, at elevations of $500-700 \mathrm{~m}$ a.s.1, being crossed by numerous water courses originated from the glaciar cirques or the mountain slopes. The density of the hydrographical net is high, reaching $1.4 \mathrm{~km} / \mathrm{km}^{2}$ (Ujvári, 1972). The landscape is dominated by open habitats. In the lower part, and especially in the vicinity of localities, stretches a mosaic of small patches of agricultural fields, many of them not cultivated, invaded by a rich and tall herbaceous vegetation. Southwards from the localities large surfaces are covered with pastures, some of them with trees and shrubs. Along the watercourses and the ditches separating the cultivated fields there are stripes of unused land, covered by high mesohygrophilous or even hygrophilous vegetation. Forests are poorly represented in the area, mainly as small patches of mixed broadleaf woods. The montane forest belt begins in the upper part of the piedmont, at the limit with Făgăraş Mountains.

The first data published on the small mammals from Făgăraş Depression date back to the $19^{\text {th }}$ century, being published by E. A. Bielz (1888), who notes from the area two species of shrews and four species of rodents. Some of these data were later taken over by Călinescu in his synthesis published in 1931. The study on rodents from Retezat and Făgăraş Mountains (Hamar, 1958) included also information on species found at lower elevations, especially Arpaşu de Sus and Bâlea Valley. More recently, a list of the vertebrates from Țara Făgăraşului (Făgăraş Mountains 
and Depression) was published by Ardelean \& Trifonof (2000). The list includes 7 species of shrews and 15 species of rodents ( 13 of them from the piedmont) and may contain some errors. „Fauna României. Rodentia” (Popescu \& Murariu, 2001) also contains some information on the species from Făgăraş Depression, partly original, partly older data cited from literature.

Between 2010 and 2011 a survey of small mammal communities from different habitat types was carried out in the Făgăraş Piedmont. The study took place in the frame of the project LIFE08 NAT/RO/000501- „Conservation of Aquila pomarina in Romania", co-ordinated by the Regional Environmental Protection Agency Sibiu, Romanian Ornithological Society and the Association for Bird and Nature Protection „Milvus Group”.

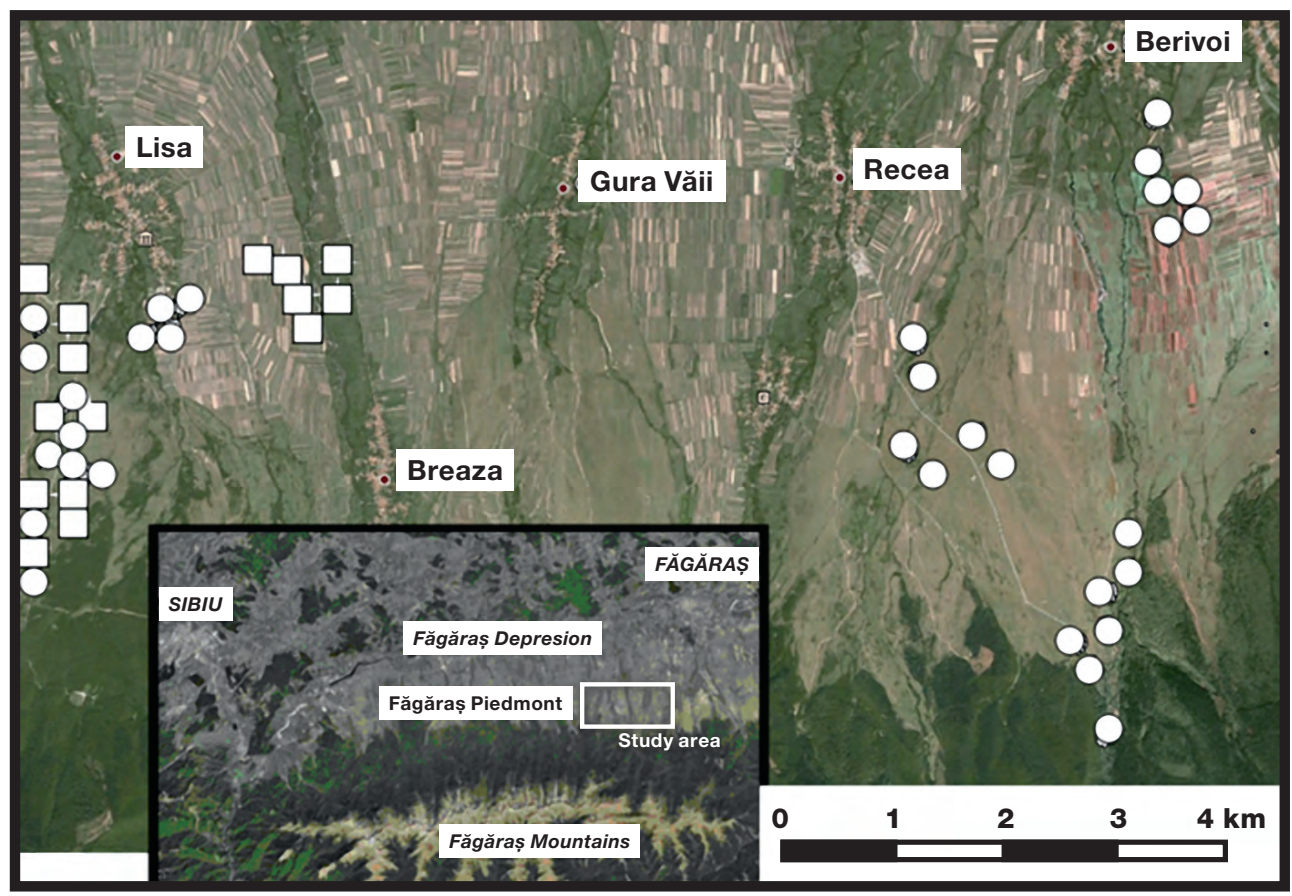

Fig. 1 - Position of the study area in Făgăraş Depression and the placement of trap lines in the three researched localities (the symbol $\square$ indicates the transects set in 2010 and $\circ$ those from 2011)

\section{STUDY AREA AND METHODS}

In autumn 2010 one field campaign was carried out in two localities from Făgăraş Piedmont, namely Lisa and Breaza. In 2011, the survey took place during two campaigns, one in summer, the second in autumn (beginning with mid-August), in Lisa and Berivoi. The survey was carried out by means of CMR (capture-markrelease) method, using plastic handmade box traps set in lines in different habitats. Each transect included 33-40 traps, placed at $10 \mathrm{~m}$ distance, one trap per point. Five transects were set at the same time, and traps were checked for three consecutive nights, at dawn. In all 61 transects were set in 9 habitat types (pastures, hayfields, wooded pastures, unused lands, cornfields, potato fields, fields of grain, abandoned 
cultures, wooded pastures, and forest edges). The trap lines' position is indicated in fig. 1. The number of transects set in each habitat type was proportional to the ratio of that habitat type in the area, so that the results give a sound image of the structure and abundance of small mammal communities from the investigated zones.

The traps were baited with sunflower seeds and apple slices. No prebaiting was done. The captured specimens were identified to species based on morphological characters, marked by cutting the fur on the rear part of the back, and released. Recaptures are not considered in the data analysis.

Relative abundance was expressed as the ratio of the species (in percents) within the community, frequency was calculated as the ratio of transects (in percents) where the species was captured, and abundance, as a measure of population density, was expressed as capture index, meaning the number of captured individuals per 100 active trap-nights. A total of 4717 active trap-nights effort (of the intended 7320) was used during the survey, as many traps were disturbed by animals (especially shepherd dogs), rain, or wind, destroyed by tractors or cows, or even stolen.

\section{RESULTS}

During the field campaigns a total number of 491 individuals were captured, belonging to 14 species, three shrews and 11 rodents. Other two species were identified based on direct or indirect visual observations. The data collected during the research period are presented in table 1 . For each species the relative abundance ( $\mathrm{RA} \%)$ and frequency (F\%) were calculated.

The list of the terrestrial small mammal species from Făgăraş Depression (including the piedmont), based on the data collected during the field campaigns and the information from literature, is presented below. To avoid repetitivity, the bibliographic sources, presented in the Introduction, are referred to only by the authors. Systematics is given according to Wilson \& Reeder (2005).

Table 1

Terrestrial small mammals captured in the localities from Făgăraş Piedmont, in 2010 and 2011.

\begin{tabular}{|c|c|c|c|c|c|c|c|}
\hline \multirow{2}{*}{ Species } & \multicolumn{2}{|c|}{ Lisa } & \multirow{2}{*}{$\begin{array}{l}\text { Breaza } \\
2010\end{array}$} & \multirow{2}{*}{$\begin{array}{l}\text { Berivoi } \\
2011\end{array}$} & \multirow[t]{2}{*}{ Total } & \multirow[t]{2}{*}{ RA\% } & \multirow{2}{*}{$\mathrm{F} \%$} \\
\hline & 2010 & 2011 & & & & & \\
\hline S. araneus & 2 & 5 & 0 & 5 & 12 & 2.44 & 16.39 \\
\hline S. minutus & 0 & 1 & 0 & 0 & 1 & 0.20 & 1.63 \\
\hline C. suaveolens & 0 & 1 & 0 & 0 & 1 & 0.20 & 1.63 \\
\hline A. amphibius & 0 & 2 & 0 & 1 & 3 & 0.61 & 4.91 \\
\hline C. glareolus & 0 & 1 & 0 & 3 & 4 & 0.81 & 6.55 \\
\hline M. arvalis & 7 & 45 & 44 & 25 & 121 & 24.64 & 52.45 \\
\hline M. subterraneus & 0 & 5 & 0 & 1 & 6 & 1.22 & 8.19 \\
\hline M. minutus & 0 & 0 & 1 & 0 & 1 & 0.20 & 1.63 \\
\hline A. agrarius & 38 & 40 & 47 & 98 & 223 & 45.41 & 65.57 \\
\hline A. flavicollis & 4 & 26 & 1 & 50 & 81 & 16.49 & 22.95 \\
\hline A. sylvaticus & 1 & 6 & 14 & 11 & 32 & 6.51 & 21.31 \\
\hline A. uralensis & 0 & 1 & 0 & 0 & 1 & 0.20 & 1.63 \\
\hline M. musculus & 0 & 2 & 0 & 2 & 4 & 0.81 & 6.55 \\
\hline M. avellanarius & 0 & 1 & 0 & 0 & 1 & 0.20 & 1.63 \\
\hline Total & 52 & 136 & 107 & 196 & 491 & 100 & \\
\hline
\end{tabular}


Order Erinaceomorpha

Family Erinaceidae

1. Erinaceus roumanicus Barret-Hamilton, 1900 (Eastern hedgehog) Ardelean and Trifonof mention it as a widely spread species in Țara Făgăraşului, frequent in gardens, shrubs, and orchards, without citing any locality.

Order Soricomorpha

Family Soricidae

2. Sorex araneus Linnaeus, 1758 (Common shrew) - was first cited from the area in the $19^{\text {th }}$ century by Bielz, from Avrig and Cârţişoara, at $640 \mathrm{~m}$, the information being later taken over by Călinescu. More recently, Ardelean and Trifonof note its presence in forested areas, but also in gardens or in the vicinity of houses. In the research area the Common shrew was captured in different habitat types from Lisa and Berivoi, recording a relatively high frequency considering its abundance.

3. Sorex minutus Linnaeus, 1766 (Pygmy shrew) - Ardelean and Trifonof mention it from Făgăraş Depression up to 1300 m, with no specific location. One specimen of pygmy shrew was captured in a wooded pasture from Lisa in September 2011.

4. Neomys fodiens (Pennant, 1771) (Water shrew) - Ardelean and Trifonof note it as frequent in the vicinity of water courses, being observed along Bâlea, Porumbacu, and Viştea rivers.

5. Crocidura leucodon (Hermann, 1780) (Bicoloured white-toothed shrew) Ardelean and Trifonof cite it in Făgăraş Depression and Piedmont, in small numbers, preferring dry meadows, clearings, gardens, and forest edges.

6. Crocidura suaveolens (Pallas, 1811) (Lesser white-toothed shrew) - was first mentioned in the area as $C$. aranea by Bielz from Avrig, and later by Ardelean and Trifonof as C. mimula, in low numbers, from Olt River floodplain up to the mountains, preferring open habitats, gardens, and cultivated fields, sometimes being found also in the vicinity of houses. One specimen was captured in a potato field at Lisa in July 2011.

Family Talpidae

7. Talpa europaea Linnaeus, 1758 (European mole) - Ardelean and Trifonof note it as a widely distributed species, preferring vegetable gardens, pastures, and hayfields. No locality is mentioned. During our study an individual was found dead on a road.

\section{Order Rodentia}

Family Sciuridae

8. Sciurus vulgaris Linnaeus, 1758 (Red squirrel) - was first mentioned from Făgăraş Piedmont by Bielz, and later by Ardelean and Trifonof as present in all forests from Țara Făgăraşului.

Family Gliridae

9. Glis glis (Linnaeus, 1866) (Fat dormouse) - according to Ardelean and Trifonof, inhabits broadleaf forests from Ţara Făgăraşului, as well as orchards with walnut trees. 
10. Muscardinus avellanarius (Linnaeus, 1758) (Hazel dormouse) - was first cited in the Făgăraş Piedmont by Bielz, from Cârţişoara. It is considered a common species in Ţara Făgăraşului in all types of forests by Ardelean and Trifonof, as well as in areas with hazelnut shrubs. One single specimen was captured in a wooded pasture from Lisa in June 2011.

11. Eliomys quercinus (Linnaeus, 1866) (Garden dormouse) - was mentioned from the area only by Ardelean and Trifonof, as less widely spread than the previous species, in broadleaf, and especially oak forests, being observed in Dumbrava Vadului (Şercaia locality) and Podei Forest (Arpaşu de Sus locality).

\section{Family Cricetidae}

12. Ondatra zibethicus (Linnaeus, 1766) (Muskrat) - entered Făgăraş Depression in the years 1965-1970, in the present it inhabits rivers, channels, lakes, and ponds up to the foot of the mountains (idem).

13. Arvicola amphibius (Linnaeus, 1758) (Water vole) - is widely spread in the area, preferring pastures, meadows, orchards, and gardens with humid soil (idem). During our study three specimens were captured in cereals and abandoned fields from Lisa and Berivoi.

14. Clethrionomys (= Myodes) glareolus (Schreber, 1780) (Bank vole) - was first recorded in the area by Bielz. Later Hamar noted that the Bank vole represents the most abundant species in spruce forests, being present down to $700 \mathrm{~m}$. It is mentioned by Ardelean and Trifonof from forests with undergrowth up to $1000 \mathrm{~m}$, this limit being strongly underestimated. In "Fauna României. Rodentia" the Bank vole is cited from Făgăraş Mountains in forests situated between 700-1700 m a.s.l. During our study it was rarely captured, at Lisa and Berivoi, in humid habitats with trees and high herbaceous vegetation, or at the forest edge.

15. Microtus arvalis (Pallas, 1778) (Common vole) - was first recorded from the area by Hamar, who collected it near Arpaşul de Sus. Ardelean and Trifonof consider the Common vole the most widely distributed rodent from Ţara Făgăraşului, inhabiting especially cultivated fields. During our research $M$. arvalis was captured from the three research areas in all the habitats except the forest edge. The highest capture index was calculated for the cornfield.

16. Microtus (Terricola) subterraneus (de Selys-Longchamps, 1836)(Common pine vole) - is considered by Hamar to inhabit in Făgăraş Mountains clearings with rich herbaceous vegetation above $700 \mathrm{~m}$ elevation, being most abundant in the alpine zone, as all the captured specimens come from around Bâlea and Capra lakes, at aprox. $2000 \mathrm{~m}$ a.s.l. During our research 6 specimens were captured from Lisa and Berivoi in humid habitats with high and rich vegetation.

17. Chionomys nivalis (Martins, 1842) (Snow vole) - is mentioned by Ardelean and Trifonof from the hilly area up to $2000 \mathrm{~m}$, preferring sunny places, on scree or rocky areas, while Hamar notes that it inhabits only rocky areas from the subalpine zone, with grasses and mountain pine shrubs, all the specimens being captured from Bâlea Valley and on the lake shore. According to our observations, in Făgăraş Mountains the Snow vole inhabits the alpine area up to the highest peaks, being spotted in several places along the mountain ridge between Negoiu and Vânătoarea lui Buteanu peaks. In other massifs it was found also in montane forests, down to $850 \mathrm{~m}$, along mountain valleys (Benedek et al., 2002; Benedek, 2008; Sike \& Gubányi, 2003-2004). However, the presence of the Snow vole in Făgăraş Depression, at elevations below $700 \mathrm{~m}$, is questionable. 
Family Muridae

18. Micromys minutus (Pallas, 1771) (Harvest mouse) - was first recorded from the area in the $19^{\text {th }}$ century, by Bielz, from Făgăraş. According to Ardelean and Trifonof it inhabits gardens, orchards, clearings, forest edges, and reedbeds along waters. One specimen of harvest mouse was captured in an abandoned field from Breaza in October 2010.

19. Apodemus agrarius (Pallas, 1771) (Striped field mouse) - was first mentioned in Făgăraş Piedmont by Hamar from the vicinity of Arpaşul de Sus and Bâlea Valley, in humid places. The Striped field mouse was the prevailing species in the three research localities, being captured in all the habitat types except the forest edge. The species, common in open habitats from Transylvania, was overlooked in the list drawn up by Ardelean and Trifonof.

20. Apodemus flavicollis (Melchior, 1834) (Yellow-necked mouse) - is a widespread species in forested areas, mentioned by Hamar from Făgăraş Mountains down to the forest limit. The species, common in all types of forests from Transylvania, was overlooked in the list drawn up by Ardelean and Trifonof. The Yellow-necked mouse was captured in habitats with woody vegetation or situated in the vicinity of the forest, in all the investigated localities, being more abundant at Lisa and Berivoi.

21. Apodemus sylvaticus (Linnaeus, 1758) (Wood mouse) - was cited by Ardelean and Trifonof as one of the most common species from Ţara Făgăraşului, in oak and beech forests but it was probably partially confused with the previous species. According to Hamar the Wood mouse does not inhabit compact forests and does not occur above 700-750 m. During our research the Wood mouse was found in all the three localities, being more abundant in Breaza. It was trapped in open habitats, and especially in cultivated fields (the highest capture index was calculated for the potato field).

22. Apodemus uralensis (Pallas, 1811) (Pygmy field mouse) - is not cited in the literature from Făgăraş Depression. One specimen was captured in a cereals field at Lisa in July 2011.

23. Mus musculus Linnaeus, 1758 (House mouse) - was found everywhere in inhabited buildings by Hamar. According to Ardelean and Trifonof it is widespread in the area, especially in households. During the study several specimens of House mouse were captured from Lisa and Berivoi in potato and abandoned fields.

24. Rattus norvegicus (Berkenhout, 1769) (Brown rat) - Ardelean and Trifonof consider it as frequent around the deposits of garbage and in human settlements. During the study it was observed in households from Berivoi locality.

The terrestrial small mammal communities from the research area are dominated by rodents, and among them by mice species belonging to Apodemus genus (Fig. 2). A. agrarius represents almost half of the captured specimens (45.41\%) and records the highest frequency, being trapped in $65.57 \%$ of the transects. $A$. agrarius is followed by $M$. arvalis, both in what relative abundance $(24.64 \%)$ and frequency $(52.45 \%)$ are concerned. A. flavicollis was found in few habitat types, mainly at the forest edge $(\mathrm{F}=22.95)$, where it reaches high densities $(\mathrm{RA}=16.5 \%)$.

No significant association was found between the three dominant species from the investigated area, their high proportion of co-occurrence being determined rather by their high frequency then by similar habitat preferences.

All the other small mammals present low ratios and frequencies. Five species (S. minutus, C. suaveolens, A. uralensis, M. minutus, M. avellanarius) were 


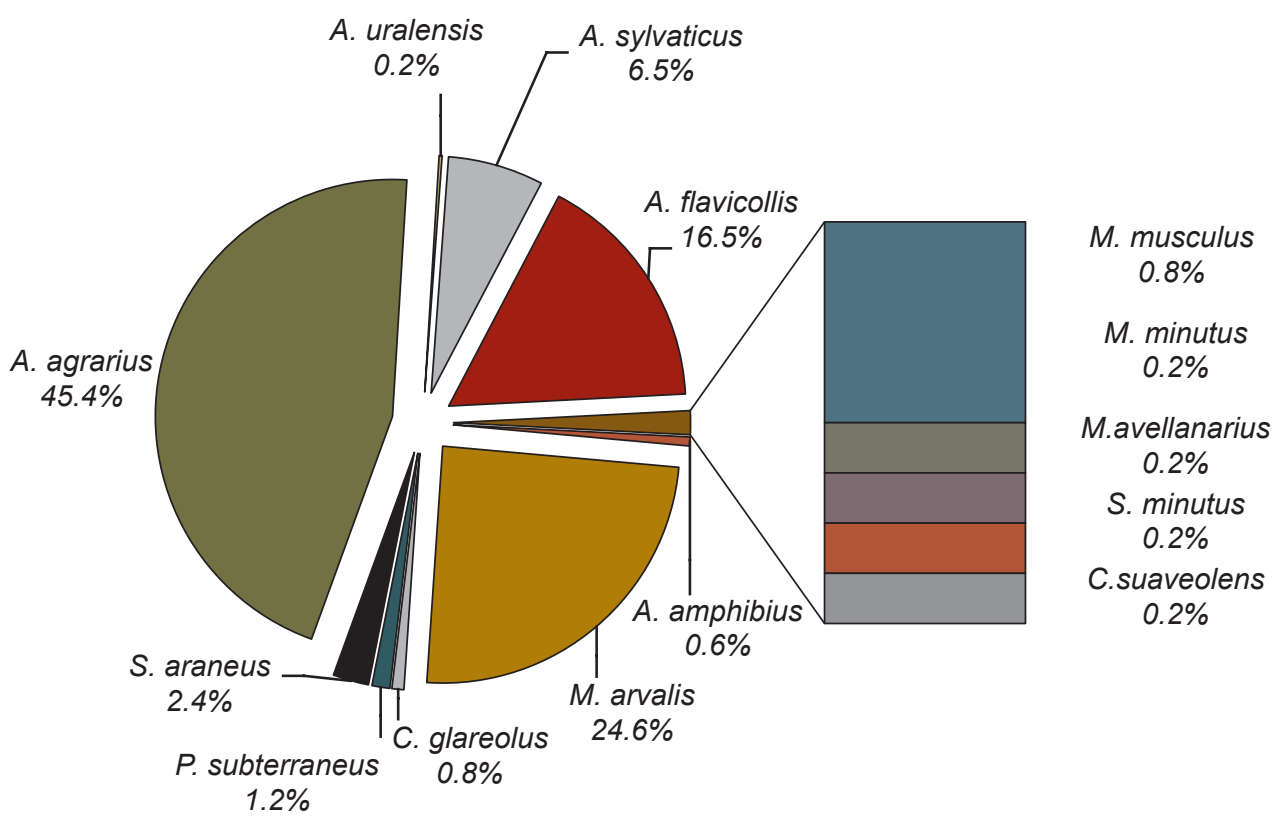

Fig. 2 - Relative abundance of terrestrial small mammal species captured in Făgăraş Piedmont during the research.

represented by only one specimen (RA $=0.2 \%, \mathrm{~F}=1.63 \%$ ). Among the shrews $S$. araneus prevailed, with $2.44 \%$ of the captured individuals.

There is a very significant $(\mathrm{p}<0.001)$, strong $(\mathrm{r}=0.963)$ and positive correlation between the relative abundance and frequency calculated for the captured small mammals.

Considering separately the three investigation areas (Fig. 3), the Pearson chi-square test of independence shows a very significant $(p<0.001)$ dependence of the small mammal community structure (considering only the prevailing species, A. agrarius, A. flavicollis, $A$. sylvaticus, and $M$. arvalis) on the locality, the most

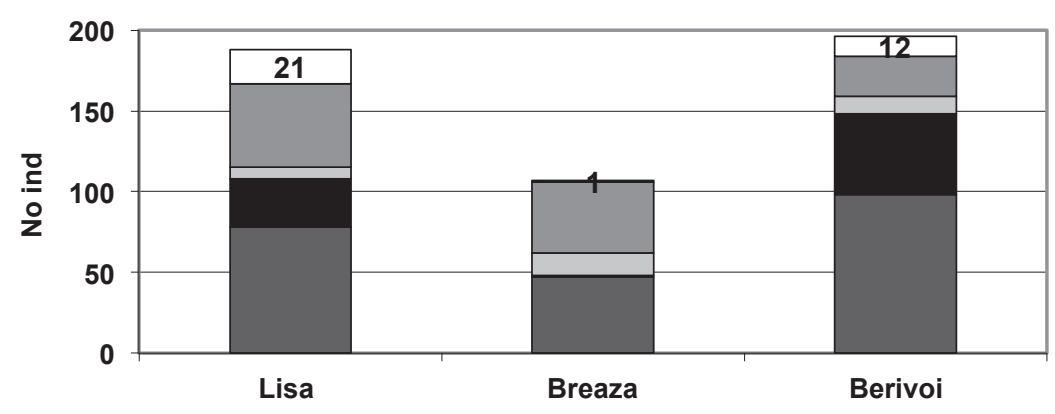

\begin{tabular}{|lll}
\hline$\square$ agrarius $\square$. flavicollis $\square$ A.sylvaticus $\square$. arvalis $\square$ other \\
\hline
\end{tabular}

Fig. 3 - The number of small mammals captured in the three research areas and the total values of the capture index (IC). 


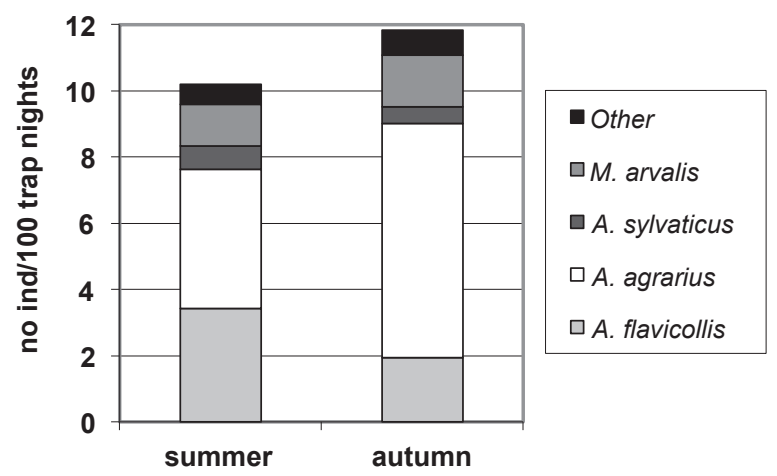

Fig. 4 - The abundance of small mammal community from Berivoi in the two research campaigns.

distinctive being Breaza. A characteristic feature of the small mammal community from the area surveyed in this locality is its low specific diversity; only five species were captured (besides the four dominant rodents, one specimen of M. minutus was found). Another distinctive characteristic is the shift in ratio between the two species of Sylvaemus subgenus, namely A. flavicollis and A. sylvaticus, at Breaza only one specimen of A. flavicollis was found, representing $0.96 \%$. From the quantitative point of view Breaza stands out by the significantly higher value of the capture index (28.98 compared to 7.34 at Lisa and 10.89 at Berivoi).

At Lisa investigations were carried out both in 2010 and 2011, but due to the changes occurred, the researched habitats were mostly different, so no comparison is to be made between the community abundance and structure between the two years. In 2011, the survey took place in the same habitats in summer and autumn in both localities. At Lisa, considering the prevailing species (A. agrarius, M. arvalis, and A. flavicollis), the community structure was not dependent on season $(\mathrm{p}=0.218)$. The total capture index had also very similar values (10.74 in summer and 10.31 in autumn), due to the fact that the second field campaign took place in late August and early September, before the emergence of the new generation, indicating a rather late reproduction season.

At Berivoi (Fig. 4), considering the four most abundant species (A. agrarius, A. flavicollis, M. arvalis, and A. sylvaticus), there is a significant dependence of their

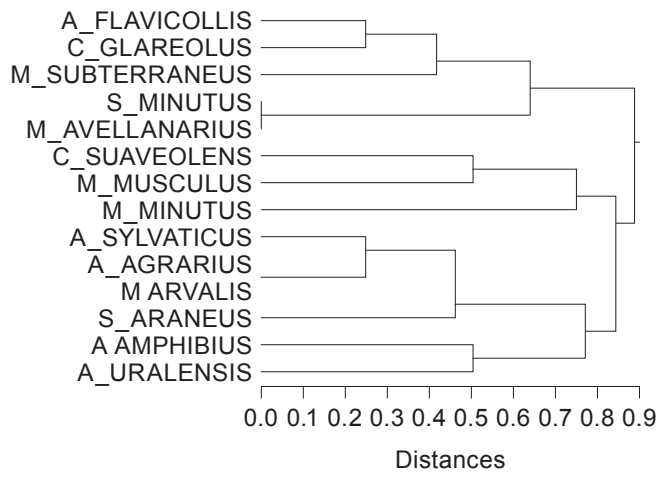

Fig. 5 - Cluster analysis of the terrestrial small mammal species based on presence-absence (Jaccard index) in the investigated habitat types (average linkage method) 
ratio on the season $(\mathrm{p}=0.022)$. In autumn $A$. flavicollis seems to retreat from some of the investigated habitats, thus the increase in the community's density (IC $=10.18$ in summer and $\mathrm{IC}=11.84$ in autumn) is reduced, although the second survey took place in October.

The cluster analysis of the small mammal species based on presence-absence (Jaccard index) in the investigated habitat types (Fig. 5) reveals three groups of species formed at distances greater than 0.6. The main group contains a cluster formed of six species, among which A. agrarius and M. arvalis present a $100 \%$ similarity. A second group includes species (C. suaveolens, M. musculus, $M$. minutus) with low frequencies. The last cluster joins five species, among which $S$. minutus and $M$. avellanarius present a $100 \%$ overlap, but were captured in only one transect.

In the pastures (I.C. $=1.6)$ and hayfields $($ I.C. $=5.5)$, where the lowest densities were recorded (Fig. 6), only the same three species were captured (A. agrarius, $M$. arvalis, and $S$. araneus $)$. However, no significant $(\mathrm{p}=0.210)$ correlation was found between the number of species and the values of capture index in the nine habitat types. Cornfields shelter the most abundant rodent communities (I.C. $=20.8$ ), but the specific diversity is low (3 species). The maximum number of species (9) was captured in the wooded pastures (I.C.=14.2). In unused terrains and abandoned fields both the species number ( 6 and respectively 9 ) and the capture index (I.C. $=20.7$ and 18) were high. Unused lands bordering the riverside coppices have a high density of A. flavicollis, which is the prevailing species also at the forest edge.

The cluster analysis of the investigated habitat types based on Euclidean distances between the capture index of small mammal species (Fig. 7) shows three groups formed at a similar distance (between 1.5 and 1.8), each joining three habitat types. The first cluster includes forest edges, wooded pastures, and unused lands.

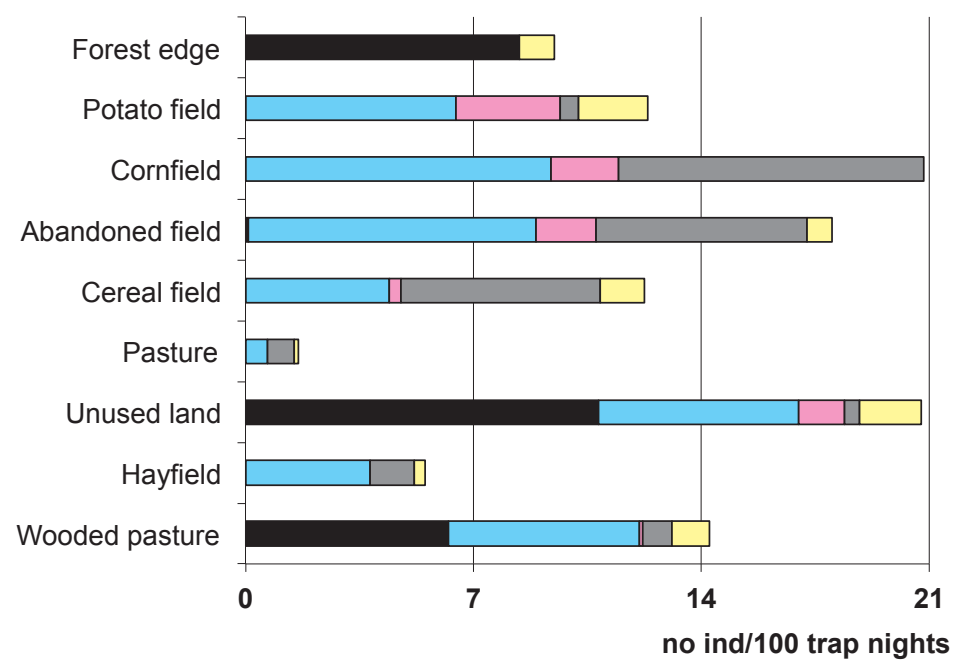

- A. flavicollis $\square$ A. agrarius $\square$ A. sylvaticus $\square$ M. arvalis $\square$ Other

Fig. 6 - Abundance and species diversity of small mammal communities in the investigated habitat types. 
The second group joins pastures, hayfields, and potato fields, and the last group is formed of habitats represented by fields (cereals, abandoned, and cornfields).

Except for the species represented by a single captured specimen, all the small mammals were found in more than one habitat type (Fig. 8). The two dominant rodents, $A$. agrarius and $M$. arvalis, were found to inhabit all the researched habitat types except the forest edge, both having a higher abundance in abandoned fields. A. sylvaticus was captured in six of the nine investigated habitat types, missing at the forest edge, in the hayfields and pastures. It shows an affinity for abandoned cultures, a relatively high proportion of individuals being captured also in the potato fields.

Most of the M. musculus specimens were captured in potato fields, while none was found in cornfields, as it would have been expected. A. flavicollis and $C$. glareolus have similar habitat preferences, being captured mostly in the same habitat types (wooded pastures, unused land, and forest edges). The habitat preferences of $M$. subterraneus in the research area resemble those of yellow-necked mice, but it was not trapped at the forest edges and in abandoned fields. S. araneus was captured in small numbers in a variety of habitats (wooded pastures, hayfields, pastures, cereal fields, and abandoned cultures).

\section{DISCUSSIONS}

In the investigated area the high abundance of the striped field mouse is determined partly by the relatively high humidity of the area, due to the proximity of the mountains, the montane forest belt, and the numerous streams and rivers crossing the piedmont, but also by the numerous cultivated fields which were surveyed, as both moisture and presence of crops (especially potato and corn) favour this species. The humidity and presence of potato and corn fields, which are favourable for the striped field mouse, have a limiting effect on the numerical development of the common vole populations. A typical forest species, the yellow-necked mouse is not favoured by the open areas that were mainly surveyed, so it was captured only in the habitats with woody vegetation, especially at the forest edge. Shrews were poorly represented among the captured specimens, partly due to the selectivity of the live traps, which are not too sensitive for very small animals, and the lack of suitable bait.



Fig. 7 - Cluster analysis of the investigated habitat types based on Euclidean distances between the capture index of small mammals species (average linkage method). 


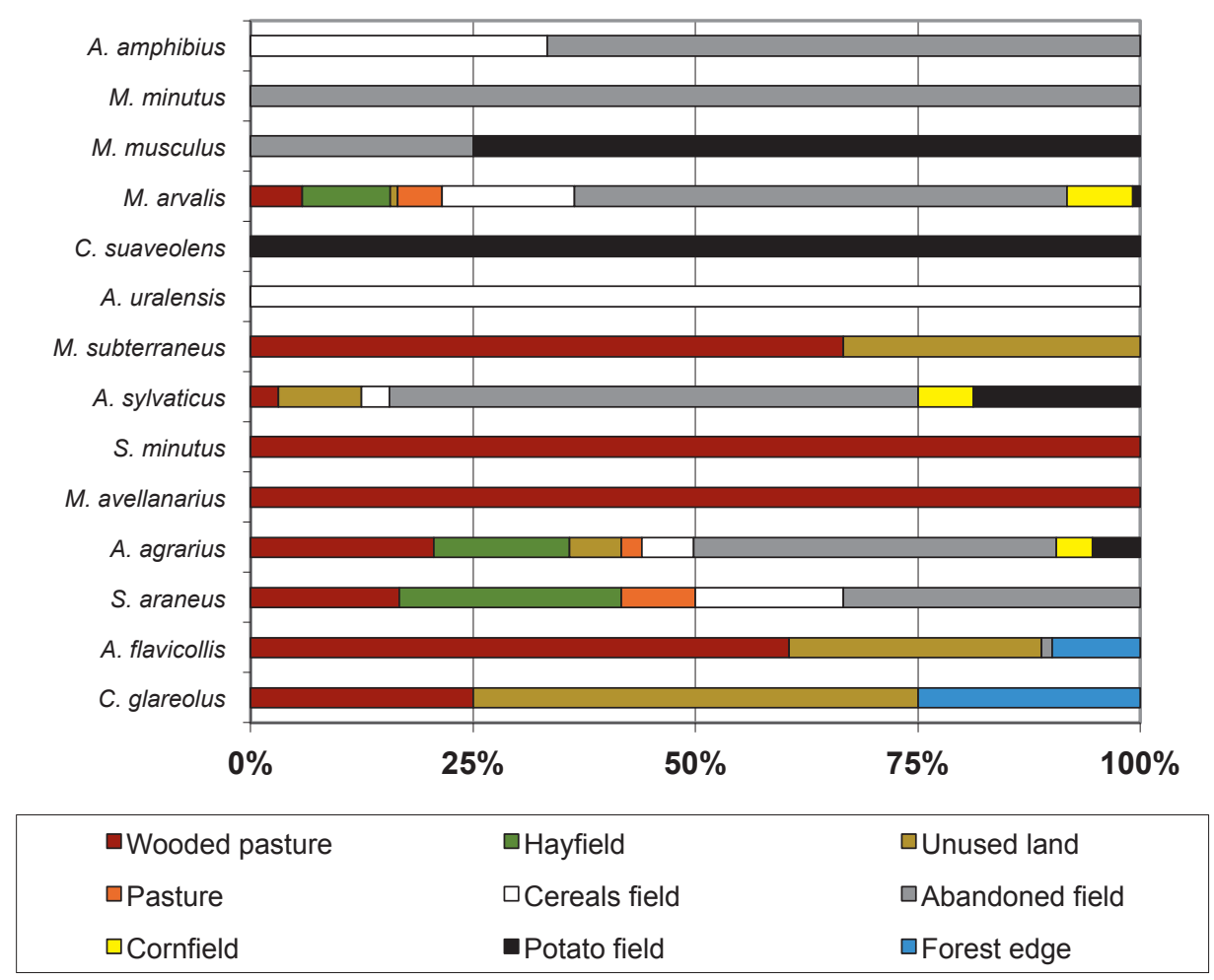

Fig. 8 - Relative occurrence of small mammal species in the investigated habitat types

The characteristics of the small mammal community from Breaza are determined by the structure of the landscape, mostly a mosaic of patches of abandoned fields, with little woody vegetation, far from the montane forest belt, suitable for open habitat rodents, especially the striped field mouse and the common vole, reaching the highest density in autumn, when the survey took place.

Based on their presence in different habitat types, the terrestrial small mammal species from the investigated area form three clusters. The first group includes the species dependent on woody vegetation (the Yellow-necked mouse, Bank vole, Common pine vole, Hazel dormouse), found mainly at the forest edge and in wooded pastures. The second cluster joins species captured in abandoned cultures and potato fields (the House mouse, Lesser white-toothed shrew, and Harvest mouse). However, due to their low frequency and abundance, these results do not necessarily reflect their real affinities. The last group is formed of the euryoecious species (the Striped field mouse, Common vole, Wood mouse, and Common shrew) joined by the two species found mainly in grain fields, namely the Water vole and Pygmy field mouse.

Cornfields present the highest densities of rodents, which find here, during summer and especially autumn, a suitable shelter provided by the high vegetation, and a source of food. However, only a few species use these habitats, the specific diversity being low. The presence of rodents in cultivated fields is not constant, depending on the food and shelter availability and the agricultural works (Hamar \& Şutova, 1965, 1968; Theiss, 1962). The most diverse communities are sheltered by 
heterogenous habitats, with mixed vegetation, representing a mosaic of numerous microhabitats, which offer suitable conditions to several species of small mammals. The maximum number of species was captured in the wooded pastures, where the trees and shrubs allow the coexistence of typical forest (Bank vole, Hazel dormouse, Yellow-necked mouse) and open habitat species (Common vole). Unused terrains and abandoned fields are habitats with high herbaceous vegetation, characterized by a low human disturbance, thus they shelter both rich and diverse communities.

Based on the abundance of small mammal populations they shelter, the 9 investigated habitat types form three clusters. The first group joins the habitats with trees and shrubs or situated next to the forest, where the Yellow-necked mouse prevails in the community: forest edges, wooded pastures, and unused lands. The second group includes pastures, hayfields, and potato fields - habitats with low abundances of small mammals, where the Striped field mouse is most abundant. The last cluster is formed of habitats represented by fields (cereals, abandoned, and cornfields) with abundant small mammal communities, where the Striped field mouse and Common vole are co-dominant. The last two groups, having the Striped field mouse as a common element, unite well before joining the first group. Thus, the habitats with woody vegetation have small mammal communities distinct from those from open habitats, the presence of trees and shrubs being one of the main habitat factors shaping community structure.

The two dominant rodents, the Striped field mouse and the Common vole, inhabit all the researched habitat types except the forest edge, both showing a preference for abandoned fields, stronger in the Common vole. Compared to the Striped field mouse, the Common vole has a higher occurrence in cereal fields, but is less abundant in wooded pastures and unused lands, where the presence of trees and shrubs and the higher humidity favour other species. The Wood mouse has a high ecological plasticity, showing an affinity for abandoned cultures and potato fields. It is adapted to inhabit a wide range of open habitats with rich herbaceous vegetation, including different types of cultures, but avoiding compact forests as well as habitats with short vegetation. This fact is in concordance with the results of some previous studies (Benedek, 2008; Benedek \& Sîrbu, 2009; Hamar, 1958), but does not confirm the conclusions of other authors (Istrate, 1998), who claim that the Wood mouse is, like its name indicates, mainly a forest dweller. The Yellow-necked mouse and the Bank vole have similar habitat preferences, but the latter is more dependent on forests and moisture, thus it presents a higher occurrence at the forest edge and the unused lands along the ditches and rivers. The habitat preferences of the Common pine vole in the research area resemble those of the Yellow-necked mouse, but it was not captured at the forest edges and in abandoned fields, probably only due to its low densities, as in other areas the species was found both in forests (Hamar \& Şutova, 1965; Benedek, 2006; Benedek, 2004), and in abandoned fields (Benedek et al., unpublished data). Outside localities the house mice are linked mainly to agricultural land, either cultures or abandoned fields. The large variety of habitats where the Common shrew was found during the study confirms that it is a euryoecious species, inhabiting both open and forested habitats (Banaru, 1998; Istrate, 1998; Murariu, 2003; Benedek, 2006; Benedek \& Sîrbu, 2009).

\section{Conclusions}

During the research period a total number of 491 individuals were captured, belonging to 14 species (three species of shrews and 11 of rodents). Terrestrial small mammal communities were dominated by Apodemus agrarius, followed by Microtus arvalis and Apodemus favicollis, which recorded also the highest frequencies. 
Between species abundance, expressed as capture index, and frequency in the research area a significant positive correlation was found. In one of the localities (Berivoi) a significant change in the community structure took place in autumn, along with an increase in density. Although only seasonally inhabited, cultivated fields provide during summer and especially autumn suitable conditions for some species, which develop abundant populations. Thus, the highest capture index was calcualted for the cornfields. The most diverse communities are sheltered by heterogenous habitats (wooded pastures and unused lands), with mixed vegetation, representing a mosaic of numerous microhabitats, which offer suitable conditions for several species of small mammals.

\section{ACKNOWLEDGEMENTS}

The present study took place in the frame of the project LIFE08 NAT/RO/000501"Conservation of Aquila pomarina in Romania”, co-ordinated by the Regional Environmental Protection Agency Sibiu, Romanian Ornithological Society and Association for Bird and Nature Protection „Milvus Group”. We are grateful to the coordinators of this project, especially to Alexandru Nicoară, project manager, and Atilla Kecskes from Milvus Group, for offering us the opportunity of this research.

\section{COMUNITĂŢI DE MAMIFERE MICI TERESTRE DIN PIEMONTUL FĂGĂRAŞ (ROMÂNIA)}

\section{REZUMAT}

Până în prezent sunt cunoscute din Piemontul Făgăraş 24 de specii de mamifere mici terestre, dintre care una (Chionomys nivalis) necesită o confirmare ulterioară, prezenţa ei la această altitudine fiind pusă sub semnul întrebării. În anii 2010 şi 2011 s-au desfăşurat în Piemontul Făgăraş trei campanii de teren care au urmărit structura comunităţilor de mamifere mici din diferite habitate investigate în trei localităţi, prin utilizarea metodei de captură-marcare-eliberare. În total au fost instalate 61 de transecte de capcane în 9 tipuri de habitate. Au fost capturate 491 de mamifere mici aparţinând la 14 specii, trei de insectivore şi 11 de rozătoare. Cele mai ridicate densităţi au fost înregistrate în culturi şi terenuri neutilizate, diversitatea specifică nefiind însă corelată cu abundenţa.

\section{LITERATURE CITED}

ARDELEAN, G., P. TRIFONOF, 2000 - Vertebratele din Țara Făgăraşului. Studii și Comunicări, Seria Ştiințele Naturii, Satu Mare, 1: 333-362. (in Romanian)

BANARU, V., 1998 - Cercetări faunistice, ecologice, biometrice şi de biologie privind populaţiile de micromamifere (Insectivora, Rodentia) din Bazinul Someşului Mic, România. PhD thesis, "Babeş-Bolyai" Univ. Cluj-Napoca: 1-368. (in Romanian)

BENEDEK, A. M., 2004 - Aspects regarding the small mammal communities (Ord Insectivora and Ord. Rodentia) from the Sibiu Depression, based on Strix aluco and Asio otus pellets. Acta oecologica Univ. Lucian Blaga, Sibiu, 11 (1-2): 209-216.

BENEDEK, A. M., 2006 - Small mammals (Ordo Insectivora and Ordo Rodentia) from Retezat National Park (Romania). Transylvanian Review of Systematical and Ecological Research, 3: $139-146$.

BENEDEK, A. M., 2008 - Studii asupra mamiferelor mici (Ordinele Insectivora şi Rodentia) în Transilvania - România. PhD thesis, Univ. of Bucharest: 1-317. (in Romanian)

BENEDEK, A. M., I. SÎRBU, 2009 - Small Mammals (Ord. Insectivora and Ord. Rodentia) community's seasonal dynamics in Cefa Nature Park (Bihor County, Romania) between 2005 and 2008. Travaux du Muséun National d'Histoire Naturale "Grigore Antipa", 52: 387394.

BENEDEK, A. M., I. SÎRBU, M. COȚOFANĂ, 2002 - Study on the small mammal communities from the Lotrioara River Basin (Lotru Mountains). Travaux du Muséun National d'Histoire Naturale "Grigore Antipa", 44: 455-464.

BIELZ, E. A., 1888 - Die Fauna der Wierbeltiere Siebenbürgens nach ihrem gegenwartigen Stande. Verhandlungen und Mitteilungen des Siebenbürgisches Vereins für Naturwissenschaften zu Hermannstadt, 38: 15-36. 
CĂLINESCU, R., 1931 - Mamiferele României. Repartiţia şi problemele lor biogeografice-economice. Buletinul Ministerului Agriculturii și Domeniilor, 251 (1): 1-103. (in Romanian)

HAMAR, M., 1958 - Notă preliminară asupra faunei rozătoarelor din Retezat şi Făgăraş. Natura, 10 (5): 86-91. (in Romanian)

HAMAR, M., M. ŞUTOVA, 1965 - Studiul ecologic al mamiferelor (Mammalia) din agrobiocenozele din Dobrogea şi Bărăgan. Comunicări de Zoologie, 3: 37-66. (in Romanian)

HAMAR, M., M. ŞUTOVA, 1968 - Cercetări privind gradul de stabilitate a populaţiilor de rozătoare din agrobiocenoze. Studii şi cercetări. Seria Zoologie, 20 (6): 593-600. (in Romanian)

ISTRATE, P., 1998 - Les petits mammifères du Plateau Târnava, Transylvanie. Travaux du Muséun National d'Histoire Naturale "Grigore Antipa", 40: 449-474.

MURARIU, D., 2003 - The faunal state and the estimation of the preservation categories of the mammal species of Piatra Craiului National Park. Research in Piatra Craiului National Park: 289-300.

POPESCU, A., D. MURARIU, 2001 - Rodentia. In: Fauna României, Mammalia, 16 (2): 1-214. Edit. Acad. Române. (in Romanian)

SIKE, T., A. GUBÁNYI, 2003-2004 - Contribuţii la cercetarea faunei de mamifere mici din România. Studii și Comunicări, Seria Ştiințele Naturii, Satu Mare, 4-5: 205-207. (in Romanian)

THEISS, F., 1962 - Contribuţii la studiul dinamicii populaţiei şi a migraţiei la rozătoare mici. Natura, 14 (2): 56-61. (in Romanian)

UJVÁRI, L., 1972 - Geografia apelor României. Edit. Ştiinţifică, Bucureşti: 305-306. (in Romanian)

WILSON, D. E., D. A. M. REEDER (eds), 2005 - Mammal Species of the World. A Taxonomic and Geographic Reference (3rd ed.). Available at www.bucknell.edu/msw3.

Received: July 30, 2012

Accepted: December 18, 2012
Anamaria Lazăr, Cătălin Lazăr

"Transylvania" University of Braşov, Faculty of Food and Tourism

Eroilor Bd. 29, RO-500362, Braşov, Romania

University of Bucharest, Faculty of Biology,

Biology Doctoral School

M. Kogălniceanu Bd. 36-46, RO - 050107,

Bucureşti, Romania

e-mail: anagurzau@yahoo.co.uk

Ana Maria Benedek, Ana Maria Șuvăială

Lucian Blaga" University of Sibiu, Faculty of Sciences

Dr. Ion Raţiu St. 5-7, RO - 550012, Sibiu, Romania

e-mail: benedek_ana@yahoo.com 